\title{
Revisiting the quality of exports
}

\author{
Gerardo Fujii-Gambero* and Manuel García-Ramos
}

*Correspondence:

fujii@unam.mx

Facultad de Economía,

College of Economics,

National Autonomous

University of Mexico (UNAM),

Edificio B, Cubículo 112, Av.

Universidad No. 3000, Ciudad

Universitaria, Delegación

Coyoacán, 04510 México,

Mexico

\section{焦 Springer}

\begin{abstract}
In the context of world value chains, the manner in which production occurs has made more difficult to judge countries' export quality, given that the international division of labor is arranged around phases of the production process, some of which are sophisticated and others uncomplicated. When a country specializes in complex processes, it adds more value to output than countries specializing in basic transformation. For this reason, we examine two indicators of export quality based on a decomposition of the value of exports. The first indicator involves breaking down value added (VA) embodied in exports by country of origin (domestic or foreign VA), and the second distinguishes between the use that exporting countries make of products that they import: either to produce their own exports or for other uses. Our empirical information from 2009 refers to 22 economies whose indicators are examined both for total exports and for the types of goods exported.
\end{abstract}

Keywords: Quality of exports, Value added embodied in exports by origin, Domestic and foreign value added, Value added embodied in the rest of the world's exports, Statistics on trade in value-added database

JEL Classification: F14

\section{Introduction}

In economics there is no debate that exports are important for economic growth. The currents of thought that link one concept with another are embedded in microeconomics and macroeconomics. Within the past few years, however, growing attention has been afforded to the mesoeconomic aspect of this relationship, by which we mean that the quality of exports, as determined by their composition, seen from several perspectives, is also vital for growth. The purpose of this paper is to examine quality of exports in the context of international fragmentation of production. Fragmented production gives rise to trade among countries that can be examined from two perspectives: on one hand, the imported content of a country's exports and, on the other, part of a country's exports can be used by importing countries to produce their own exports.

Most research on this subject has focused on the quality of exports of countries that export high-technology goods and whose production is integrated in global value chains. Among the countries that participate in the global production of these goods, the international division of labor is distributed among countries that assemble the final good from imported parts and components and so their exports are very intensive in imports, while other countries specialize in the design and engineering phases of output, organizing the parts and components production's chain, producing high-value parts,

(c) 2015 Fujii-Gambero and García-Ramos. This article is distributed under the terms of the Creative Commons Attribution 4.0 International License (http://creativecommons.org/licenses/by/4.0/), which permits unrestricted use, distribution, and reproduction in any medium, provided you give appropriate credit to the original author(s) and the source, provide a link to the Creative Commons license, and indicate if changes were made. 
organizing the supply chain to countries that specialize in product assembly, distributing the final good worldwide, and in post-sale servicing. Exports from assembling countries are characterized by a low domestic value-added content, while exports of countries that specialize in processing and producing components (to be used by assembling countries in order to produce final goods for export) have a high value-added component.

International fragmentation of the value chain does not occur exclusively in high-technology goods. It also takes place among countries that produce and export raw materials and semi-manufactured goods and importing countries that process, add value, and then export these goods. Therefore, the value of these products exported by a country that processes imported raw materials can also be differentiated by the origin of the value, i.e., between foreign value added (generated in the country of origin of the raw material), and domestic value added, which is the value added by processing the raw material that is later exported. Viewed from a raw material-exporting country, importing countries use these raw materials to produce exports or use them for other purposes.

These two types of fragmentation in the value chain have been given specific names: upstream links (foreign value added embodied in exports), and downstream links (exports that are incorporated in goods produced by other countries and then reexported) (UNCTAD 2013: 131).

The purpose of this paper is to examine countries' export quality from the double perspective mentioned before: first, how much domestic value added is embodied in exports (which is the flip side of foreign value added in exports), and, second, what use is made of a particular country's exports in importing countries.

From the first perspective, domestic value added embodied in exports acts as an indicator of export quality, given that it shows countries' domestic-income content in their exports. The higher it is, exports will have a greater multiplier effect on domestic demand and, thus, on economic growth. Therefore, countries will be in a position to overcome the alternative they generally face between export-led growth or domestic demand-led growth. If the domestic income embodied in exports is high, the export-led growth model will kick-start domestic demand and, from the perspective of demand, growth will be doubly grounded, i.e., both foreign and domestic demand.

From the second perspective, and evaluation of export's quality depends on the role they will play in the importers' production process -i.e. as inputs to produce exports or for other uses. If exports are raw materials or natural resource-intensive manufactures processed by other countries as exports, the share of these products in the exports of the origin country indicates the potential amount of VA that it could incorporate if it increased domestic processing of raw materials that are currently exported. If they are technology-intensive manufactures that are exported as final goods with a high imported content, export quality would be low, even if the country is exporting technologically sophisticated products, but if an important amount of this kind of exports is used by importing countries to produce exports, this may be a sign that the country is specializing in producing parts and components, or is specializing in those phases of production processes that are very intensive in generating value.

This paper is structured as follows: In "Sect. 1.2", we review the literature on the subject of export quality. In "Sect. 2", we discuss the method for quantitative analysis of VA in countries' exports from two perspectives: from the viewpoint of countries where 
VA originates, and from the perspective of how importing countries use those exports. "Sect. 3" analyses export quality focusing on domestic VA embodied in exports by country, and relates data of domestic VA in exports with their composition. At the end of "Sect. 3", we take up export quality focusing on how exports are used by importing countries, either to produce exports or for other uses in two types of manufacturing exports: those intensive in natural resources and those intensive in technology. The paper ends with its conclusions, their possible relevance in defining policies aimed at improving export quality from the analytical perspective of this paper, and a proposal for further research suggested by our findings.

Data refer to a sample of 22 economies (20 with the highest GDP plus Argentina, in 29th place, and South Africa, in 30th place, to widen the sample of countries whose primary exports make up an important part of total exports).

All data come from OECD-WTO (2013), statistics on trade in value added database.

\subsection{Literature review}

Export quality is not studied in classical international trade theory. For Ricardo, it was just as advantageous to export cloth as it was to export wine. Prebisch (1949) sparked debate on the topic when he asserted that it is more advantageous to export manufactured products than primary products, since, in the long run, the terms of trade will tend to move in favor of manufactures, given their higher demand. Furthermore, prices of manufactured goods produced in countries of the economic "core" (using Prebisch's terminology) are downwardly rigid, while prices of primary products, exported by periphery countries, are downwardly flexible, given the institutional framework of the labor market in wealthy or poor countries. Later on, using this same viewpoint, ECLAC (1995) revisited the dynamism in world demand for different types of goods, which led it to classify export products by country, according to the relationship between the dynamism of world demand for each product and the growth of exports for that particular product in a given country. ECLAC classified exports by one of four categories: rising stars, missed opportunities, retreats, and waning stars (Mandeng 1991). More recently, the problem of quality in exports has led economists to address the matter from several viewpoints. One approach emphasizes export diversification, to help overcome the instability of exports (Ghosh and Ostry 1994; Bleaney and Greenaway 2001), and increasing learning opportunities that can encourage development of comparative advantages in new products (Gutiérrez de Piñeres and Ferrantino 2000; Agosin 2009; Lederman and Maloney 2007; Hesse 2008). Another approach evaluates exports by levels of sophistication and addresses the topic by taking into account the association between the composition of exports and countries' per-capita income levels, in the understanding that richer countries have more sophisticated exports (Lall et al. 2006; and Hausmann et al. 2007).

The indicators used by the latter approach are based on product classification established by the Standard International Trade Classification (SITC), a system which, in the context of an increasingly fragmented world production in certain branches of production, limits our perception of the technological level of exports based on products. Lall et al. (2006) posit two concepts that characterize exports: sophistication and technological level. While the sophistication indicator arises from the correlation between countries' income levels and their composition of exports, the technological level, developed 
by Lall (2000), is defined by the intensity of R\&D in products. This leads us to differentiate between high-technology exports with a low level of sophistication, and low-technology exports with a high level of sophistication. In a context of fragmented production, the first group covers technology-intensive goods that are assembled by semi-industrialized countries and then exported. Although statistics show these countries' exports to be sophisticated, by specializing in the assembly of high-technology products for export, the fact that they participate in technologically simple phases of high technology is concealed. The second group, low-level technology but sophisticated exports of developed countries, encompasses manufactured goods based on natural resource transformation.

Another focus of recent research using this same approach is derived from the concept of space-product, which estimates the possibility of diversifying the export mix in accordance to the closeness of goods within a given country's production structure (Hausmann and Klinger 2006). There are grounds to think that, for goods within a fragmented international production structure, this concept suffers from the same limitation in evaluating export quality as the correlation between per-capita income and export composition. It is much more relevant for both approaches to establish the closeness among production processes.

A different approach to understand this problem is based on calculating the unit price of exports (Rodrik 2006). To derive export quality of products from these calculations, we need to compare the unit prices of the same good exported by different countries, under the assumption that higher unit prices mean higher quality of goods. Yet, this interpretation is weakened by the fact that in import-intensive exported goods, high unit prices might be due to the high price of imported parts and components.

In one of the topics explored by this paper to determine export status (by explicitly introducing the international fragmentation of output), the matter of VA in exports by country of origin has been studied particularly in countries whose exports are integrated in global value chains (GVC) to produce technology-intensive goods. Given that in this type of products the value of exports and the domestic value added integrated in them are different, two categories of countries exist: Although the value of exports may be quite high, some countries incorporate little domestic value added, given that they are involved in technologically simple phases of production of these goods; while the country that imports the final good may be re-importing value added that it itself originally generated and exported in a high-value component that is later re-imported in a finished good. Further, countries that specialize in stages that precede or follow direct production of goods are in an advantageous position, since these stages generate a good deal of value. Countries in the first category include China and Mexico, while countries in the second category include United States among others. Some of the authors who have studied this matter are Chen et al. (2005, 2008); Daudin et al. (2009); De la Cruz et al. (2011); Fujii and Cervantes (2013a, b); He and Zhang (2010); Johnson and Noguera (2011); and Koopman et al. (2008). (UNCTAD 2013, chapter 4 contains a review of research on this topic).

The indicator of domestic value added embodied in exports has been used in calculating competitiveness in terms which overcome the growing limitations of an indicator based on gross exports, given the weight that foreign value added has in the export of certain goods (Timmer et al. 2013). This indicator helps us to evaluate the quality of exports, 
given that, as domestic value added in exports increases, so does the complexity of production processes in those countries that specialize in high-technology output in the context of internationally fragmented production; also, the degree of domestic processing of natural resource-intensive manufactures before being exported increases as well.

This line of research that breaks down the value of exports by their origin and use was made possible by preparing multi-regional, input-output tables (such as UNCTAD/Eora GVC Database; OECD-WTO, Inter-Country Input-Output Model; Institute of Developing Economies (IDE-JETRO), Asian International Input-Output Tables; Purdue University, Global Trade Analysis Project (GTAP); World Input-Output Database (WIOD). These new data bases have facilitated a growing number of investigations along the lines of this paper.

\section{Methods}

Trade flows among countries can be represented by a multi-regional input-output styled matrix (Table 1). Element $\mathrm{VA}_{i j}$ is value added (VA) with origin in country $i\left(p_{i}\right)$ that is embodied in the exports of country $j\left(p_{j}\right)$, which is equivalent to the VA that is imported by $p_{j}$ from $p_{i}$ to produce its exports $x_{j}$.

Data read vertically show the origin of VA embodied in the exports of the $n$ countries that appear at the top of the columns. The origin of VA embodied in the exports of country $j$ is domestic $\left(d_{j}\right)$ and/or foreign $\left(f_{j}\right)$. The share of domestically produced value in exports is equal to domestic value added (or domestic income) embodied in them, while the foreign value integrated in exports corresponds to imports of inputs, parts, and components needed to produce exports, and represents domestic income for those economies that produce them. Therefore (assuming that there is no domestic value added in $f_{j}$ that was previously exported by the country being studied and then re-imported by that country in the imports of parts and components that are used to produce exports):

$$
x_{j}=d_{j}+f_{j}
$$

Total VA of foreign origin embodied in the exports of $p_{j}$ is equal to: $f_{j}=\sum_{i=1}^{n} \mathrm{VA}_{i j}$.

Reading the matrix horizontally reveals how the rest of the world uses exports from the countries named at the beginning of each row. The rest of the world (importing countries) can use the VA embodied in exports of $p_{i}$ to produce their own exports $\left(v_{i}\right)$

Table 1 Origin and use of VA embodied in exports

\begin{tabular}{|c|c|c|c|c|c|c|c|c|c|}
\hline & & \multicolumn{5}{|c|}{ Destination country } & \multicolumn{2}{|c|}{$\begin{array}{l}\text { Rest of the world's use } \\
\text { of VA embodied in } x_{i}\end{array}$} & \multirow[t]{2}{*}{ Exports } \\
\hline & & $P_{1}$ & $\ldots$ & $P_{\mathrm{j}}$ & $\cdots$ & $P_{\mathrm{n}}$ & $\begin{array}{l}\text { To produce } \\
\text { exports }\end{array}$ & $\begin{array}{l}\text { For other } \\
\text { uses }\end{array}$ & \\
\hline \multirow[t]{5}{*}{ Origin county } & $p_{1}$ & 0 & $\ldots$ & $V A_{1 j}$ & $\ldots$ & $V A_{1 n}$ & $v_{1}$ & $w_{1}$ & $x_{1}$ \\
\hline & $\vdots$ & $\vdots$ & $\because$ & $\vdots$ & & $\vdots$ & $\vdots$ & $\vdots$ & $\vdots$ \\
\hline & $p_{\mathrm{i}}$ & $V A_{i 1}$ & $\ldots$ & 0 & $\ldots$ & $V A_{\text {in }}$ & $v_{i}$ & $w_{i}$ & $x_{i}$ \\
\hline & $\vdots$ & $\vdots$ & & $\vdots$ & $\ddots$ & $\vdots$ & $\vdots$ & $\vdots$ & $\vdots$ \\
\hline & $p_{\mathrm{n}}$ & $V A_{n 1}$ & $\ldots$ & $V A_{n j}$ & $\ldots$ & 0 & $v_{\mathrm{n}}$ & $w_{\mathrm{n}}$ & $x_{n}$ \\
\hline \multirow{2}{*}{$\begin{array}{l}\text { Origin of VA } \\
\text { embodied in } x_{j}\end{array}$} & Foreign & $f_{1}$ & $\ldots$ & $f_{j}$ & $\ldots$ & $f_{\mathrm{n}}$ & & & \\
\hline & Domestic & $d_{1}$ & $\ldots$ & $d_{\mathrm{j}}$ & $\ldots$ & $d_{n}$ & & & \\
\hline Exports & & $x_{1}$ & $\ldots$ & $x_{j}$ & $\ldots$ & $x_{n}$ & & & \\
\hline
\end{tabular}


and/or other uses apart from producing goods and services for export $\left(w_{i}\right)$, whether this means making consumer or investment goods that the importing economy employs for these purposes, or, if we consider final goods, used directly for consumption and investment. Thus:

$$
x_{i}=v_{i}+w_{i}
$$

Total VA in exports from $p_{i}$ for the rest of the world to make its exports is equal to: $v_{j}=\sum_{i=1}^{n} \mathrm{VA}_{i j}$.

For $n$ countries, Eqs. (1) and (2) are contained in Table 1.

\section{Results and discussion}

\subsection{Value of exports and domestic value added embodied in exports}

Table 2 lists the $d_{i} / x_{i}$ coefficient for the 22 selected economies with respect to the value of exports for 2009. The countries are grouped into eight categories based on the magnitude of the coefficient. There is a large variability of $d_{i} / x_{i}$ among countries; for some, it is greater than $90 \%$ of exports, while South Korea's drops as low as $59 \%$. The weighted average of the indicator is $77.6 \%$. We conclude from these data that no correlation exists between the share of domestic income embodied in exports and the level of per-capita income. Brazil and Russia's exports have the highest content of $d_{i}$, and among the middle and low categories (as determined by this indicator) we find quite a number of developed and middle-income countries.

\subsection{Domestic value added embodied in exports and composition of exports}

The last line of Table 3 shows $d_{i} / x_{i}$ for exports classified as primary (agriculture, hunting, forestry, and fishing; mining and quarrying), natural resource-intensive manufactures (food products, beverages, and tobacco; textiles, textile products, leather, and footwear; wood, paper, paper products, printing and publishing; chemicals and non-metallic mineral products; and basic metals and fabricated metal products), technology-intensive manufactures (machinery and equipment, electrical and optical equipment, and transport equipment), and services (wholesale and retail trade; hotels and restaurants; transport and storage, post and telecommunications; financial intermediation; business services; and other services). Significant differences exist in the $d_{i} / x_{i}$ coefficient by type of good. Exports of primary products and services contain more domestic income (93 and $90 \%$ of export value, respectively.) In natural resource-intensive manufactured exports, the coefficient is significantly lower $(73 \%)$, and technology-intensive exports show the lowest content of domestic value added $(71 \%){ }^{1}$

Therefore, the countries' $d_{i} / x_{i}$ coefficient depends to some extent on the composition of exports. The table shows the composition of exports for the 22 selected countries in descending order, from highest to lowest $d_{i} / x_{i}$ coefficient. The composition of exports is shown in terms of the four categories of goods mentioned previously. From this information we can draw the following initial conclusions:

${ }^{1}$ Since these figures are from 2009, the $d_{i} / x_{i}$ indicator in exports of primary products and some natural resource-intensive manufactures may have been significantly influenced by the high price of these products at that time. 


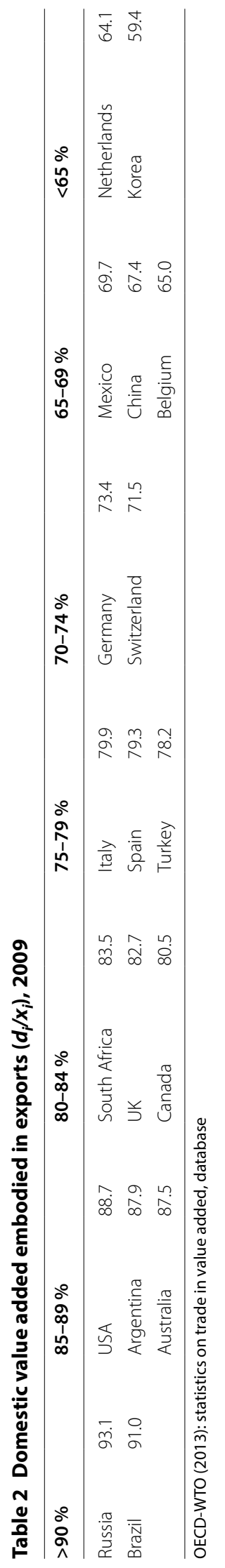


Table 3 Domestic value added embodied in exports and composition of exports, 2009

\begin{tabular}{|c|c|c|c|c|c|c|c|c|}
\hline \multirow[t]{2}{*}{ Country } & \multicolumn{2}{|c|}{$X_{p}>15 \%$} & \multicolumn{2}{|c|}{$X_{\mathrm{nmn}}>20 \%$} & \multicolumn{2}{|c|}{$X_{\mathrm{tm}}>20 \%$} & \multicolumn{2}{|c|}{$X_{s}>15 \%$} \\
\hline & $x_{p} / x_{t}^{5}$ & $d_{\mathbf{p}} / x_{\mathbf{p}}$ & $x_{n r m} / x_{t}^{5}$ & $d_{\mathrm{nrm}} / x_{\mathrm{nrm}}$ & $x_{\mathrm{tm}} / x_{t}^{5}$ & $d_{\mathrm{tm}} / x_{\mathrm{tm}}$ & $x_{s} / x_{t}^{5}$ & $d_{s} / x_{s}$ \\
\hline Russia & 43.0 & 95.0 & 35.9 & 92.0 & - & - & - & - \\
\hline Brazil & 23.8 & 93.0 & 44.8 & 90.0 & - & - & - & - \\
\hline USA & - & - & 29.8 & 83.6 & 31.5 & 85.8 & 34.3 & 95.8 \\
\hline Argentina & 18.2 & 95.0 & 51.8 & 88.0 & - & - & 16.8 & 92.0 \\
\hline Australia & 42.2 & 91.1 & 29.9 & 81.7 & - & - & 20.7 & 91.4 \\
\hline Indonesia & 22.1 & 95.8 & 50.3 & 85.0 & - & - & - & - \\
\hline Japan & - & - & 24.6 & 80.4 & 59.9 & 84.9 & 15.3 & 94.3 \\
\hline South Africa & 42.4 & 89.3 & 31.3 & 77.2 & - & - & 15.7 & 90.3 \\
\hline UK & - & - & 28.4 & 76.3 & 23.4 & 72.9 & 42.9 & 91.6 \\
\hline Canada & 27.8 & 91.6 & 31.1 & 74.2 & 24.0 & 67.8 & 16.1 & 91.3 \\
\hline Italy & - & - & 43.3 & 75.2 & 35.8 & 79.3 & 18.8 & 91.1 \\
\hline Spain & - & - & 34.3 & 73.4 & 23.3 & 71.5 & 37.7 & 88.2 \\
\hline Turkey & - & - & 45.8 & 73.7 & 24.4 & 71.5 & 21.5 & 92.3 \\
\hline India & - & - & 25.1 & 78.3 & 31.1 & 64.2 & 37.1 & 86.5 \\
\hline France & - & - & 37.9 & 71.5 & 32.7 & 67.1 & 24.4 & 90.9 \\
\hline Germany & - & - & 34.2 & 66.7 & 44.8 & 71.5 & 19.5 & 88.3 \\
\hline Switzerland & - & - & 37.0 & 63.4 & 31.3 & 67.0 & 27.9 & 87.1 \\
\hline Mexico & 15.1 & 93.4 & 26.2 & 79.5 & 52.6 & 55.3 & - & - \\
\hline China & - & - & 38.1 & 69.9 & 51.0 & 61.1 & - & - \\
\hline Belgium & - & - & 45.8 & 58.0 & - & - & 32.5 & 77.3 \\
\hline Netherlands & - & - & 47.3 & 51.6 & - & - & 24.1 & 82.8 \\
\hline Korea & - & - & 27.8 & 49.4 & 54.6 & 58.8 & 17.3 & 76.9 \\
\hline Weighted average & - & 93.0 & - & 72.9 & - & 70.9 & - & 90.2 \\
\hline
\end{tabular}

$x_{p}$ primary exports, $x_{n r m}$ natural resource-intensive manufactured exports, $x_{t m}$ technology-intensive manufactured exports, $x_{s}$ exports of services, $x t_{t}$ total exports

OECD-WTO (2013): statistics on trade in value added, database

1. Of the eight countries in which primary exports are more than $15 \%$ of total exports, seven are situated at the upper portion of the table, i.e., countries with a high $d_{i} / x_{i}$ indicating that their exports contain the highest domestic VA, with no appreciable differences with respect to the weighted average.

2. In all countries, regardless of their level of development or their natural resource endowment, manufactured exports that are natural resource intensive contribute more than one-fourth of total exports. Some of these figures merit discussion: At first glance, countries such as the Netherlands, Belgium, Switzerland, and Italy are among those with few natural resources. Yet by transforming these resources, their natural resource-intensive industries contribute $47,46,37$, and $43 \%$, respectively, to their exports. At the other extreme, Mexico, supposedly richly endowed with natural resources, is classified with Japan and India in terms of the weight of exports of these products in total exports $(25 \%)$. Significant dispersion exists among countries in terms of the $d_{i} / x_{i}$ coefficient for these products, which depends on the natural resource endowment of the countries that transform them. In some countries, the coefficient is greater than 80 \% (Russia, Brazil, USA, Argentina, Australia, Indonesia, Japan, and Mexico), while in others it is below 70 \% (Germany, Switzerland, Belgium, Netherlands, and Korea). Given the weight that these products have in exports, the 
information reviewed heretofore clusters the first group of countries toward the top of the table (with the exception of Mexico). All these countries, save Japan, are wellendowed with natural resources, and the high domestic value added in their exports is explained by the fact that the raw materials used to produce them are sourced within their own economies. Since the raw materials used to make these products in Japan are basically imported, the high content of $d_{i}$ in these products exported by the Japanese economy is surely explained by the fact that the raw materials undergo an intense transformation process that leads to high value, sophisticated products. Further, the relatively low content of domestic VA in the exports of these products from the second group of countries is a result of the fact that the raw materials used to make them are imported.

3. We pointed out previously that for the set of 14 countries in which exports of these goods contribute more than $20 \%$ of the total, it is the technology-intensive exports that have the least $d_{i}$ content. Yet the coefficient for these goods shows wide dispersion among the countries; Table 3 summarizes the results. United States and Japan, at one extreme, have a $d_{i} / x_{i}$ coefficient of these exports of 86 and $85 \%$, respectively. Japan's high coefficient, together with the fact that $57 \%$ of the country's exports are made up of technology-intensive manufactures, are factors that help explain why the joint $d_{i} / x_{i}$ coefficient for Japan reaches the upper limit. At the other extreme, China's coefficient is $61 \%,{ }^{2}$ Korea's is $59 \%$, and Mexico's is $55 \%{ }^{3}$ These results, together with the large share that this category of goods has in these three countries' exports $\left(45,54\right.$, and $49 \%$, respectively), help explain why they show the lowest $d_{i} / x_{i}$ coefficients. Further, the low $d_{i}$ content in technology-intensive manufactured exports is not a characteristic solely of recently industrialized economies. Germany, France, and Switzerland also have coefficients close to the average of the 22 economies.

4. Finally, exports of services, which on average have a high $d_{i} / x_{i}$ coefficient, show little dispersion among the 22 countries, a trait shared with primary products, explained by the fact that the inputs needed to produce services are mostly of domestic origin. Nonetheless, there is a wide dispersion of the weight of this sector in exports. In the case of the United Kingdom, it is $42 \%$ of exports with high $d_{i} / x_{i}$, which helps explain why it holds the third or fourth highest $d_{i} / x_{i}$ coefficient among developed countries. These exports are also important in United States, Spain, India, Switzerland, and Belgium. Exports of the latter country have the lowest $d_{i} / x_{i}$ coefficient among the 22 countries, which together with the fact that its raw material-intensive manufactured exports have a low $d_{i} / x_{i}$ and the weight that these two types of goods have in Belgian exports help to explain why Belgium places among the four countries with the lowest $d_{i} / x_{i}$

Table 4 in the statistical appendix shows $d_{i} / x_{i}$ coefficient with a more detailed breakdown in 12 sectors for those countries whose exports from each sector make up at least

\footnotetext{
${ }^{2}$ According to Koopman et al. (2008), domestic value added in China's total manufacturing exports is $54 \%$ and is significantly lower in the electronic and electrical equipment industries.

3 According to Fujii and Cervantes (2013: 140), the coefficient is significantly lower in Mexico (34.9\% in 2003), a figure that is obtained by breaking down exports into either processing exports or the rest of the economy's exports, an aspect not considered in the OCED-WTO database.
} 
$10 \%$ of total exports. These data help us understand further some aspects highlighted in Table 3.

1. Regardless of their level of development or their relative endowment of natural resources, in all of our selected countries the fact that exports of resource-intensive manufactures have an important weight is due mainly to exports of chemicals and non-metallic mineral products, which in 18 countries contribute more than $10 \%$ of exports. In this type of goods, however, the variability of the $d_{i} / x_{i}$ coefficient is high (from 93 \% in Russia to 39 \% in South Korea).

2. The transport equipment sector is important in the exports of nine countries, and two countries stand out due to the elevated coefficient of $d_{i} / x_{i}$ : USA $(83 \%)$ and Japan (86\%). With the exception of Turkey, the coefficient in the remaining countries hovers around $65 \%$, regardless of their level of development or whether domestic companies or multinational corporations predominate in the sector. Within this sector, domestic companies are important in Germany, France, Italy, and Korea, while multinationals predominate in Spain and Mexico. Yet coefficients of domestic VA embodied in these countries' exports are very similar.

3. Japan and the Netherlands merit special attention. We have previously noted some particularities in the case of Japan, while the Netherlands stands out for being a counterpoint. The Netherlands is in next-to-last place among the 22 countries due to the domestic VA content of its exports, a situation that occurs in all of its sectors that figure prominently in Dutch exports.

\subsection{Domestic value added embodied in exports for the rest of the world's exports and the rest of the world's value added embodied in exports}

One way other authors have identified the quality of exports is through the composition of parts and components and final goods using data from UNCOMTRADE (Athukorala 2010). This indicator is based on the assumption that export quality improves as the share of parts and components increases in total exports. This information only exists for Chapter 7 (machinery and transport equipment,) including power-generating machinery and equipment; machinery specialized for particular industries; metalworking machinery; general industrial machinery and equipment, n.e.s., and machine parts, n.e.s.; office machines and automatic data-processing machines; telecommunications and sound recording and reproducing apparatus and equipment; electrical machinery, apparatus and appliances, n.e.s., and electrical parts thereof (including non-electrical counterparts, n.e.s., of electrical household-type equipment); road vehicles (including air-cushion vehicles); and other transport equipment; and Chapter 8 (miscellaneous manufactured articles that, among others, includes professional, scientific, and controlling instruments and apparatus, n.e.s.; photographic apparatus, equipment and supplies, and optical goods, n.e.s.; watches and clocks). The grounding assumption of this criterion to evaluate export quality can only be accepted as valid if we consider countries that specialize in assembling products with imported parts and components. Nonetheless, only some products included in these chapters have had international fragmentation of production. Further, even when dealing with this type of production, it seems risky to directly associate low export quality with the export of final goods. 
By dividing (2) by the exports of country $i$, the terms of the expression become the coefficients with respect to $x_{i}$.

If $v_{i} / x_{i}$ is high, an important part of exports of $i$ are made up of raw materials, parts, and components that are used as intermediate goods in the importing country to, in turn, produce exports, while, if the opposite occurs, the exports of $i$ will be mostly final goods.

The second indicator is the rest of the world's value added embodied in the exports of $i\left(f_{i} / x_{i}\right)$, in other words, the imported component of exports, which is the complement of the $d_{i} / x_{i}$ previously discussed.

We are going to work with these indicators using data from the two types of manufacturing exports: natural resource-intensive exports and technology-intensive exports. Production of these two types of exports is characterized by its international fragmentation, i.e., integrated in global value chains, even though the degree of production fragmentation may be very different depending on what product is being discussed. The most well known case of high-degree fragmentation is the production of electronic equipment. Another is production fragmentation among some countries in which natural resources bound for export are extracted and processed to some degree, as well as other countries that import these resources to continue processing and exporting them.

By associating these two indicators by magnitude, we obtain four combinations. Figure 1 illustrates these combinations for natural resource-intensive manufacturing exports, and Fig. 2 shows technology-intensive exports. In both Figures, $v_{i} / x_{i}$ is on the $\mathrm{x}$-axis and $f_{i} / x_{i}$ is on the $\mathrm{y}$-axis.

We first discuss natural resource-intensive manufactured exports. As the imported content of these exports increases, we move up the $y$-axis. Based on the magnitude of this indicator, we define two types of export patterns for these goods: in countries wellendowed in natural resources, this coefficient is low, because they process their own natural resources. The other pattern occurs in countries that export these products by importing raw materials, and so they will have a higher imported content than countries fitting the first pattern. In Fig. 1, the first pattern is represented by countries below the $\mathrm{x}$-axis, and the second pattern plots countries above the $\mathrm{x}$-axis.

Furthermore, the $\mathrm{x}$-axis indicates the degree to which economies process natural resources, whatever their origin. As we move to the right, countries export manufactured goods with less processing, and importing countries continue processing raw materials and adding value. Therefore, for countries located to the right along the $\mathrm{x}$-axis, the indicator shows the potential increase of domestic value added in exports if the level of domestic processing of natural resources were to increase.

From this discussion, we see that countries well-endowed in natural resources that are intensely processed and later exported are in quadrant III (low $f_{i} / x_{i}$ and low $v_{i} / x_{i}$ ); therefore, they have high export quality.

Quadrant II (low $f_{i} / x_{i}$ and high $v_{i} / x_{i}$ ) contains countries rich in natural resources and whose manufactures, based on their transformation, are slightly processed (low $f_{i} / x_{i}$ ). The internal processing of those raw materials is low, however, meaning that an important part of their exports is semi-processed raw materials that are later processed in other countries that export them with value added (high $v_{i} / x_{i}$ ). 
Countries whose natural resource-intensive manufactured exports are based on imported raw materials are in quadrants IV and I. Quadrant IV (high $f_{i} / x_{i}$ and low $\left.v_{i} / x_{i}\right)$ contains countries that undertake intense transformation of those raw materials, and therefore the high $f_{i}$ content of their exports is compensated by the high value added therein.

Figure 3 displays these indicators for the 22 countries' natural resource-intensive manufactured exports in 2009. The mean value of these countries' indicators defines the two axes. For $f_{i} / x_{i}$, the mean is $28 \%$ and for $v_{i} / x_{i}$, it is $25 \%$.

As discussed previously, in terms of our chosen indicators, Russia and Australia have the worst quality exports of these types of products. At the other extreme of countries well-endowed with natural resources, we find Mexico, South Africa, and Argentina, that export this type of manufactures with a high degree of processing and that, therefore, are not much used to produce exports in other countries. These countries have highquality exports for this type of goods.

In quadrant IV, there are nine countries with high-quality exports, with a relatively high $f_{i} / x_{i}$; i.e., they import primary products that are processed intensively and later exported, for which reason their $v_{i} / x_{i}$ is lower.

The combinations of indicators that refer to technology-intensive manufactured exports are shown in Fig. 2.

Quadrants IV and I correspond to low-quality exporting patterns characterized by product assembly with a large imported content. Quadrant IV (high $f_{i} / x_{i}$ y $v_{i} / x_{i}$ ) corresponds to an exporting pattern of final goods assembled with imported parts and components. Quadrant I shows countries that assemble parts and components with a large imported content.

Quadrants II and III display countries with high-quality exports. In quadrant II (low $f_{i} /$ $x_{i}$ and high $\left.v_{i} / x_{i}\right)$, we find countries that export high-value parts and components or specialize in high-value production processes (design and engineering, organization of partssupply chains, worldwide production and distribution); quadrant III shows countries that export technology-intensive manufactured goods whose production is not internationally fragmented (and so have a low $f_{i} / x_{i}$ ), and also export final goods (low $v_{i} / x_{i}$ ).

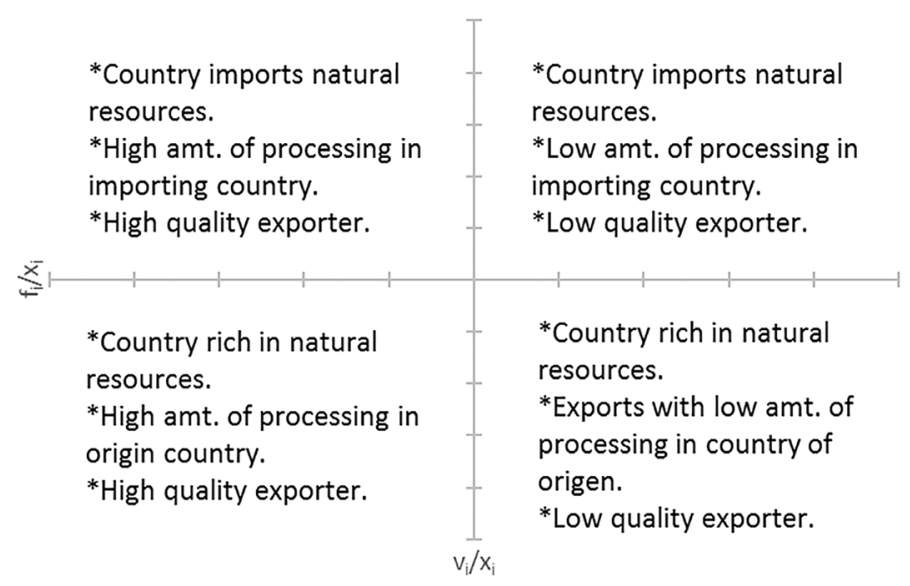

Fig. 1 Natural resource-intensive manufactured exports 


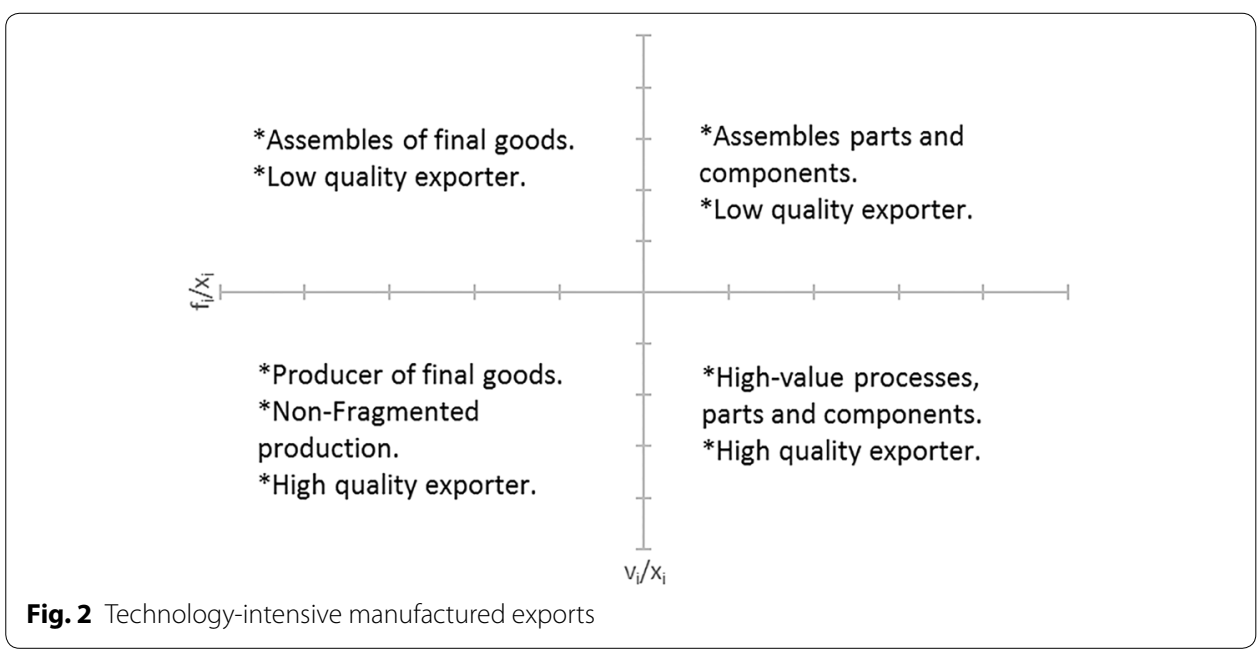

Figure 4 shows information regarding 14 countries in which technology-intensive manufacturing exports contribute more than $20 \%$ of total exports. In these countries, average $f_{i} / x_{i}$ reaches $30 \%$, while the mean of the $v_{i} / x_{i}$ indicator is $28 \%$. As demonstrated by these indicators, China and Mexico have the worst quality exports of these products (quadrant IV). The content of $f_{i}$ in their technology-intensive exports is high and is composed mainly of final goods. At the other extreme, Japan, USA, and India (quadrant II) have a low content of $f_{i}$ in their technology-intensive exports, in addition to the fact that more than $40 \%$ of the VA content therein is used by other countries to produce exports. The technology-intensive exports of the UK, Spain, and Italy have some similarity to comparable exports of the three countries that best represent quadrant II.

Between these two extremes there is an intermediate group of countries $\left(f_{i} / x_{i}\right.$ close to or higher than average), with $v_{i} / x_{i}$ somewhat below the mean. Among them we find some notable exporting powers, such as Germany, with France and Switzerland not far behind. This exporting pattern specializes in final goods, but with a near-average importing intensity. Also, Korea may be moving from quadrant IV to quadrant II: the $f_{i}$ of its technology-intensive exports are at a level similar to those of Mexico and China, although a substantially greater part of its exports of this output is made up of parts and components that importing countries use to make exports.

\section{Conclusions}

1. In economic literature, several criteria have been proposed to evaluate countries' export quality. The purpose of this paper was to suggest two additional criteria: one from the perspective of the country of origin of VA embodied in exports, domestic or foreign; the second criterion considers how the rest of the world uses exports from each country, i.e., to produce exports or for other uses.

2. We have shown herein that coefficients of domestic income embodied in exports differ from country to country and according to the product exported.

3. Export quality, focusing on that part of exports that is used to produce exports, has various interpretations according to the type of manufactures and their import intensity. 


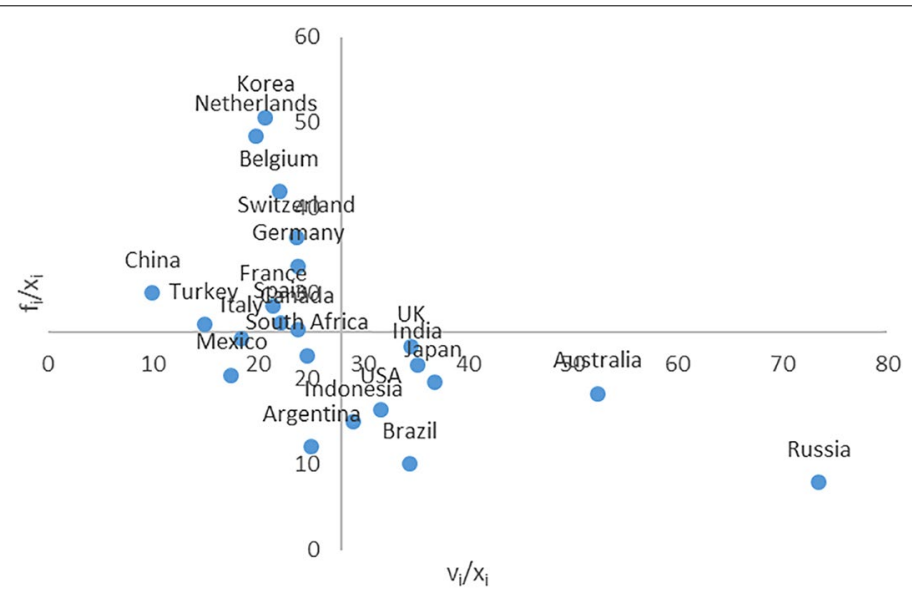

Fig. 3 Value added embodied in natural resource-intensive manufactured exports, 2009

4. From the above, we derive two policies aimed to increasing domestic income embodied in exports:

4.1. For natural resource-intensive manufactured exports from countries wellendowed in such resources, it is a matter of deepening the domestic processing of those resources.

4.2. For technology-intensive manufactured exports with low domestic value added, there are two possible measures to increase domestic value added embodied in exports. This first measure requires changing the place these countries hold in the value chain, moving from areas where little value is added and developing production processes that add abundant value. The second option is to reduce the imported content in these exports by producing parts and components domestically. Yet for exports of these products involved in the GVC, this option may have limited impact.

5. Last, we highlight aspects not covered in our paper and the areas of further research that arise thereof:

5.1. One figure used in this paper refers to the domestic income embodied in exports and another figure indicates the use of exports by importers. With respect to the first figure, from the perspective of income generation to undergird domestic demand, the most relevant indicator is national income embodied in exports.

5.2. We need to know the balance between profits leaving the country by way of foreign exporting firms and a country's domestically generated VA embodied in its exports that is re-imported to produce other exports. In the case of technology-intensive exports, in which the Global Value Chains are headed by multinational corporations, in the corporations' home countries the net balance is positive, while in countries that are not their headquarters, the balance is negative. 


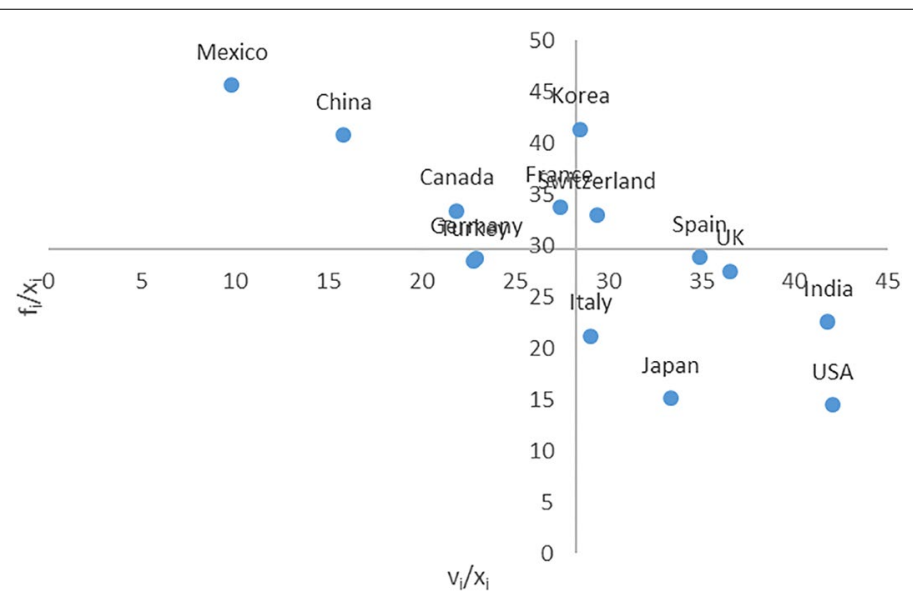

Fig. 4 Value added embodied in technology-intensive manufactured exports, 2009

5.3. With available information we can calculate domestic VA embodied in exports by product. With exports involved in the GVC, the most relevant figure is the VA by processes. To undertake this investigation would require studying the division of labor among countries by processes in specific value chains.

5.4. Finally, a more viable research project with available information would be to evaluate export quality by simultaneously using various indicators, to overcome the limitations of current research that evaluates export quality from a single perspective.

Authors' contributions

GF conceived of the study, and participated in its design and coordination and helped to draft the manuscript. MG participated in the design of the study and performed the statistical analysis. Both authors read and approved the final manuscript.

\section{Acknowledgements}

This work was sponsored by National Council of Sciences and Technology of Mexico (CONACyT), grant 10017, project 152740. We appreciate the comments of two reviewers whose observations led us to substantially improve an initial draft of this paper.

\section{Compliance with ethical guidelines}

Competing interests

The authors declare that they have no competing interests.

\section{Appendix}

See Table 4. 


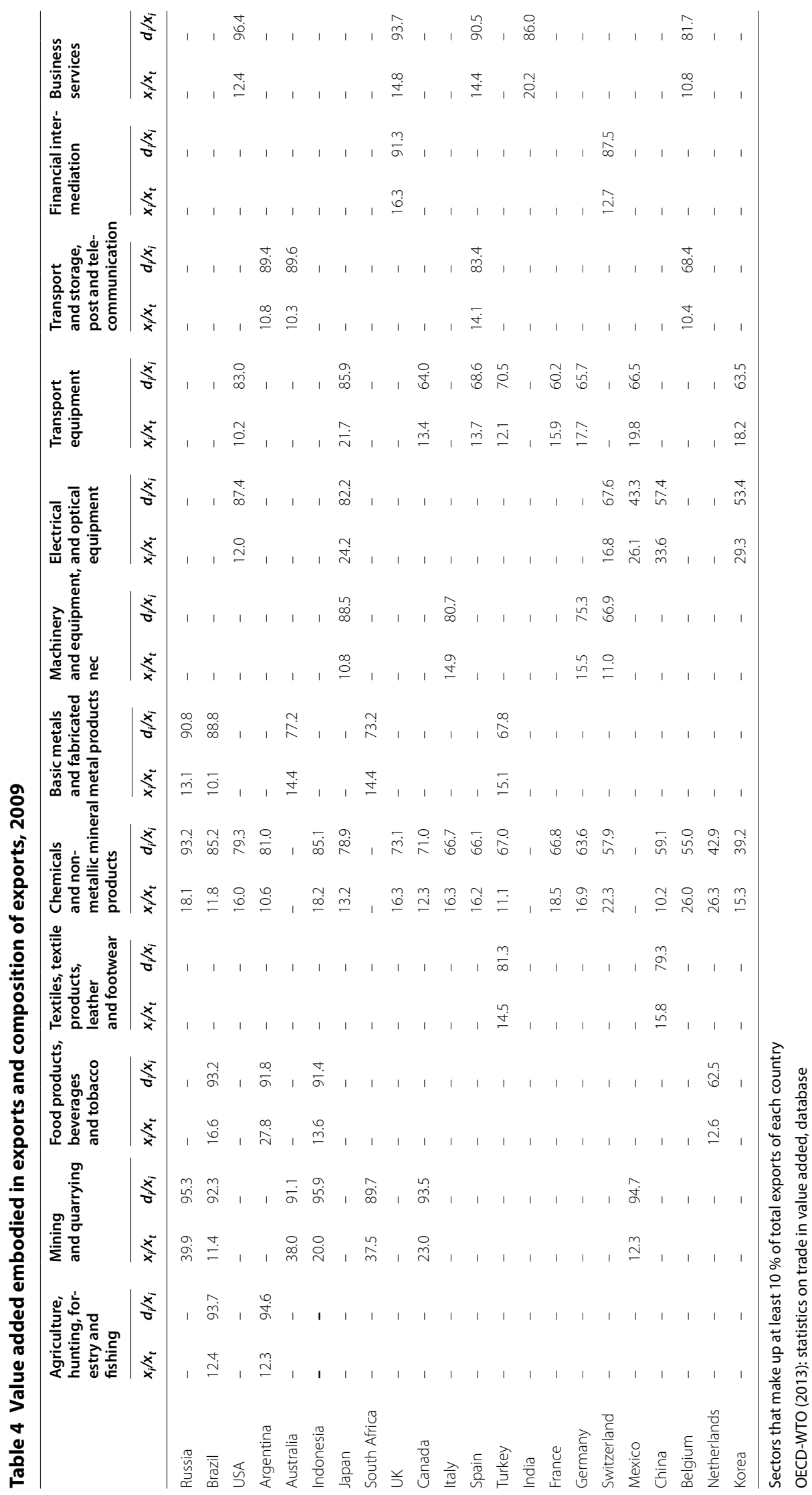


Received: 25 February 2015 Revised: 15 July 2015 Accepted: 10 September 2015

Published online: 23 September 2015

\section{References}

Agosin MR (2009) Crecimiento y diversificación de exportaciones en economías emergentes. Revista de la CEPAL No. 97 Athukorala P (2010) Production networks and trade patterns in East Asia: regionalization or globalization? Asian development bank working paper series on regional economic integration no. 56

Bleaney M, Greenaway D (2001) The impact of terms of trade and real exchange volatility on investment and growth in Sub-Saharan Africa. J Dev Econ 65:491-500

Chen X, Cheng LK, Fung KC, Lau LJ (2005) The estimation of domestic value added and employment induced by exports: an application to Chinese exports to the United States. Paper presented at the 2005 American Economic Association Meeting, Philadelphia, PA, 7-9 January 2005

Chen X, Cheng LK, Fung KC, Lau L, Sung Y, Yang C, Zhuy K, Tang Z. (2008) Domestic value added and employment generated by Chinese exports: a quantitative estimation. MPRA paper no. 15663. Munich personal RePEc archive

Daudin G, Rifflart C, Schweisguth D (2009) Who produces for whom in the world economy. Working paper no. $2009-18$. Paris, France: Observatoire Francais des Conjonctures Économiques

De la Cruz J, Koopman RB, Wang Z (2011) Estimating foreign value-added in mexico's manufacturing exports. Working paper no. 2011-04A. Washington, DC: US International Trade Commission, Office of Economics

Fujii G, Cervantes R (2013a) Mexico: value added in exports of manufactures. CEPAL Review 109

Fujii G, Cervantes R (2013b) Indirect domestic value added in mexico's manufacturing exports, by origin and destination sector. Working paper no. 760. Levy Economics Institute of Bard College, New York

Ghosh AR, Ostry J (1994) Export instability and the external balance in developing countries. IMF working paper no 94/8

Gutiérrez de Piñeres SA, Ferrantino M (2000) Export dynamics and economic growth in Latin America: a comparative perspective. Asgate, Burlington

Hausmann R, Klinger B (2006) Structural transformation and patterns of comparative advantage in the product space. Working paper no 128, Center for international development at harvard university

Hausmann R, Hwang R, Rodrik D (2007) What you export matters. J Econ Growth 12:1-25

He D, Zhang W (2010) How dependent is the Chinese economy on exports and in what sense has its growth been export-led? J Asian Econ 21:87-104

Hesse H (2008) Export diversification and economic growth. Working paper no. 21, Commission on growth and development

Johnson R, Noguera G (2011) The value-added content of trade. VOX, June 7. http://www.voxeu.org/article/ value-added-content-trade-new-insights-us-chinaimbalance

Koopman R, Wang Z, Wei SJ (2008) How much of Chinese exports is really made in China? Assessing domestic valueadded when processing trade is pervasive. Working paper 14109, Cambridge, MA: National Bureau of Economic Research

Lall S (2000) The technological structure and performance of developing country manufactured exports, 1985-98. Oxf Dev Stud 28(3):337-369

Lall S, Weiss J, Zhang J (2006) The 'sophistication' of exports: a new trade measure. World Dev 34(2):222-237

Lederman D, Maloney WF (2007) Natural resources: neither curse nor destiny. Standford University Press, Standford Mandeng OJ (1991) International competitiveness and specialization, CEPAL review, No. 45

Prebisch R (1949) El desarrollo económico de América latina y algunos de sus principales problemas, Introducción a CEPAL. Estudio económico de la América Latina, Cepal 1984

Rodrik D (2006) What so special about china's exports. NBER working paper 11947

Timmer PM, Los B, Stehrer R, de Vries G (2013) Fragmentation, incomes and jobs: an analysis of European competitiveness. Economic policy, 613-661

UNCTAD (2013) World investment report 2013. United Nations, New York

\section{Submit your manuscript to a SpringerOpen ${ }^{\circ}$ journal and benefit from:}

- Convenient online submission

- Rigorous peer review

- Immediate publication on acceptance

- Open access: articles freely available online

- High visibility within the field

- Retaining the copyright to your article

Submit your next manuscript at $\boldsymbol{s p r i n g e r o p e n . c o m ~}$ 